\title{
University Life Quality and Impact Areas
}

\author{
Ayşe Elitok Kesici ${ }^{1, *}$, Barış Çavuş ${ }^{2}$ \\ ${ }^{1}$ Department of Curriculum and Instruction, School of Education, Indiana University Bloomington, United States \\ ${ }^{2}$ School of Foreign Languages, Adnan Menderes University, Turkey
}

Copyright $\bigcirc 2019$ by authors, all rights reserved. Authors agree that this article remains permanently open access under the terms of the Creative Commons Attribution License 4.0 International License

\begin{abstract}
University life quality is a concept that affects students' self-perceptions, sense of belonging, attitudes towards the profession, alienation levels, motivations, democratic attitudes, communication skills and academic achievements in their education processes. It is affected by the open and hidden curriculum and influences these programs. Besides, this concept is influenced by the socio-economic and cultural characteristics of the society, in which individuals live. The purpose of this study is to present the concept of "university life quality" theoretically within the context of University Life Quality Model developed by Sirgy, Grezeskowiak and Rahtz (2007), to examine how the concept is embraced and in this regard and to compile the related researches. The method of this study is literature review. Within this context, the data of the study has been obtained by reviewing the related books, theses and dissertations, and articles. The concept of university life quality is a concept that is examined in a multidisciplinary manner in international literature. When the concept is examined more specifically, it can be revealed that physical facilities of the faculty, the quality of the faculty member, the family structure of the student, the readiness level of the student, the attitude of the faculty administration, the budget allocated to the faculty, cultural, art and sports activities offered to students by the faculty affect university life quality. Universities with high levels of university life quality serve to community development by yielding individual improvement and qualified work force.
\end{abstract}

Keywords University Life Quality, School Satisfaction, University Students, Hidden Curriculum, Literature Review

\section{Introduction}

Human beings wish to have a quality living throughout their lives. A quality life is the most important factor for the individual in maintaining a happy, safe and satisfied life.
Considering human as a bio-psycho-social being, we must accept that they have interests, needs and expectations throughout their lives in these areas. Achieving a life standard, taking these needs into consideration enables the individual to have a humanitarian life. Meeting these needs in university setting enhances the quality of university life. The concept of university life quality (ULQ) is universally defined as the satisfaction from university life; the satisfaction from the academic and social aspects of the university. Academic and social satisfaction is in interaction with the services and practices offered by the university (Quality of College Life Survey Report, 2009). If students develop the feeling of belonging to the faculty they are studying in, they may have a satisfied university life. This satisfaction level may improve by the fact that the courses meet the expectations of the students and that the social relationships and activities in the faculty setting have positive characteristics. The fact that all these characteristics are positive is closely related to the philosophy of school program.

The quality of life, which has been the subject of philosophy for many years, was considered in ancient and medieval times as the perfection of man, and having the highest level of virtue and the highest level of beauties. In the 1960s, it came to the forefront in taking political decisions. The reason why it is used for this purpose is that it is closely related to the life quality of education, health, and housing (Aldinç, Aytar, Demetçi, Seçen, Şahin \& Yllmaz, 2004). The fact that the income of the individual increases as their education level increases can be given as an example to this situation.

In modern societies, a very significant part of human life is spent at school. The fact that the schooling ratio of the age population is increasing seems to support this argument. Increasing social interest and state support for the preschool education and tertiary education in the recent years leads to the fact that a significant part of the lives of generations passes in formal education institutions. The organizational aim of the schools where formal education is provided differs according to educational level but mainly, the aim is to lead the students to acquire desired behaviors. Achieving this fundamental goal depends 
mainly on the effectiveness of schools (Özdemir, 2012). One of the determinants of the quality of the education provided by the schools is the high ULQ level.

The aim of the universities, which constitute a significant part of human life, is to contribute to the development of human resources through instruction and to the improvement of the life quality of people through research and counselling (Kabeta, 1999). University students continue their undergraduate education for 4 years and spend a long life in the faculties. ULQ is the fact that schools can make the students reach the targeted achievements in terms of both academic, social and psychological aspects (Sarl, 2007). Experiencing a high quality process in the faculties may enable the students to have a humanitarian life period at university, which is considered as the best years of human life. The fact that university students, who are the adults of tomorrow, are qualified will enhance community development in every area. Therefore, every study to be conducted on ULQ is thought to contribute to the field in terms of emphasizing the importance of the concept (Sar1 \& Arıkan, 2016).

The main purpose of this study is to present the concept of "university life quality" theoretically within the context of University Life Quality Model developed by Sirgy, Grzeskowiak and Rahtz (2007), to examine how the concept is embraced and in this regard, to compile the related researches.

\section{Literature Review}

In this section, the concept of ULQ, the model of ULQ, and the topics of ULQ and the Individual, ULQ and Society, and ULQ, Open Curriculum and Hidden Curriculum are discussed.

\subsection{The Concept of University Life Quality}

One of the first documents addressing the concept of life quality in the contemporary sense was the definition of the World Health Organization (WHO) in 1948. WHO defined health as a state of complete well-being in physical, mental and social terms, not only as not being sick (Akyüz, 2006). Life quality can be defined as the way of perceiving own experiences by the individual related to their expectations, standards and goals within the context of their own state, culture and value system. According to psychologists, life quality is related to the satisfaction and happiness of the individual about life (Pekel, 2016). These characteristics regarding the general life quality can also be said to be valid for ULQ.

Life quality is the way individuals assess their own states within the culture and value system. In this regard, physical functions of people, their psychological states, social relationships within and outside the family, interactions with the environment and beliefs are involved. Basically, life quality can be expressed as an individual response given in daily life to physical, psychological and social effects of the disorders affecting individual satisfaction in certain life conditions (Eser, Yüksel, Baydur, Erhart, Saatli \& Özyurt, 2008).

Universities are the top educational institutions aiming at producing qualified workforce, doing researches and developing new technologies. Therefore, they should constantly renew their understanding of administration with new social, economic, political, technological and educational ideas. In the national and international arena, the interest of "successful" students leading to competition among universities revealed the importance of student experience in assessing the university setting. As a result of these assessments, students may have tendency to select the universities with high life quality.

The concept of ULQ is also related to the "value" given to education. As well as affecting our daily life practices, values are closely related to individual and cultural development, which are responsible for historical and social changes. Furthermore, values seem to be related to the individual's beliefs and the desired goals (Schwartz \& Bilsky, 1987). For example, the fact that the individual values "education", the belief that education will be useful in their life and the point that they want to achieve in the education process are closely related to each other. The fact that students deem university valuable is affected by the quality of time spent at university.

ULQ is shaped by the factors related to university together with the academic and social experiences gained as a result of the students' involvement in university life. ULQ bases its theoretical structure upon subjective well-being (Kangal, 2012). If students feel themselves comfortable at university psychologically, it can be assumed that they have a qualified university life. ULQ is a significant concept discussed in the literature. Therefore, embodying this concept on a model is considered to make important contributions to the literature.

\subsection{University Life Quality Model}

In their study, Sirgy, Grzeskowiak and Rahtz (2007) have established a conceptual model for ULQ. They discussed this conceptual model in the dimensions as academic satisfaction, social satisfaction and satisfaction in terms of facilities and services. In this model, academic and social life satisfaction is highly significant. The satisfaction in terms of facilities and services affect the academic and social life satisfaction. The model is based on university students' life experiences at university.

Figure 1: Conceptual Model for University Life Quality 


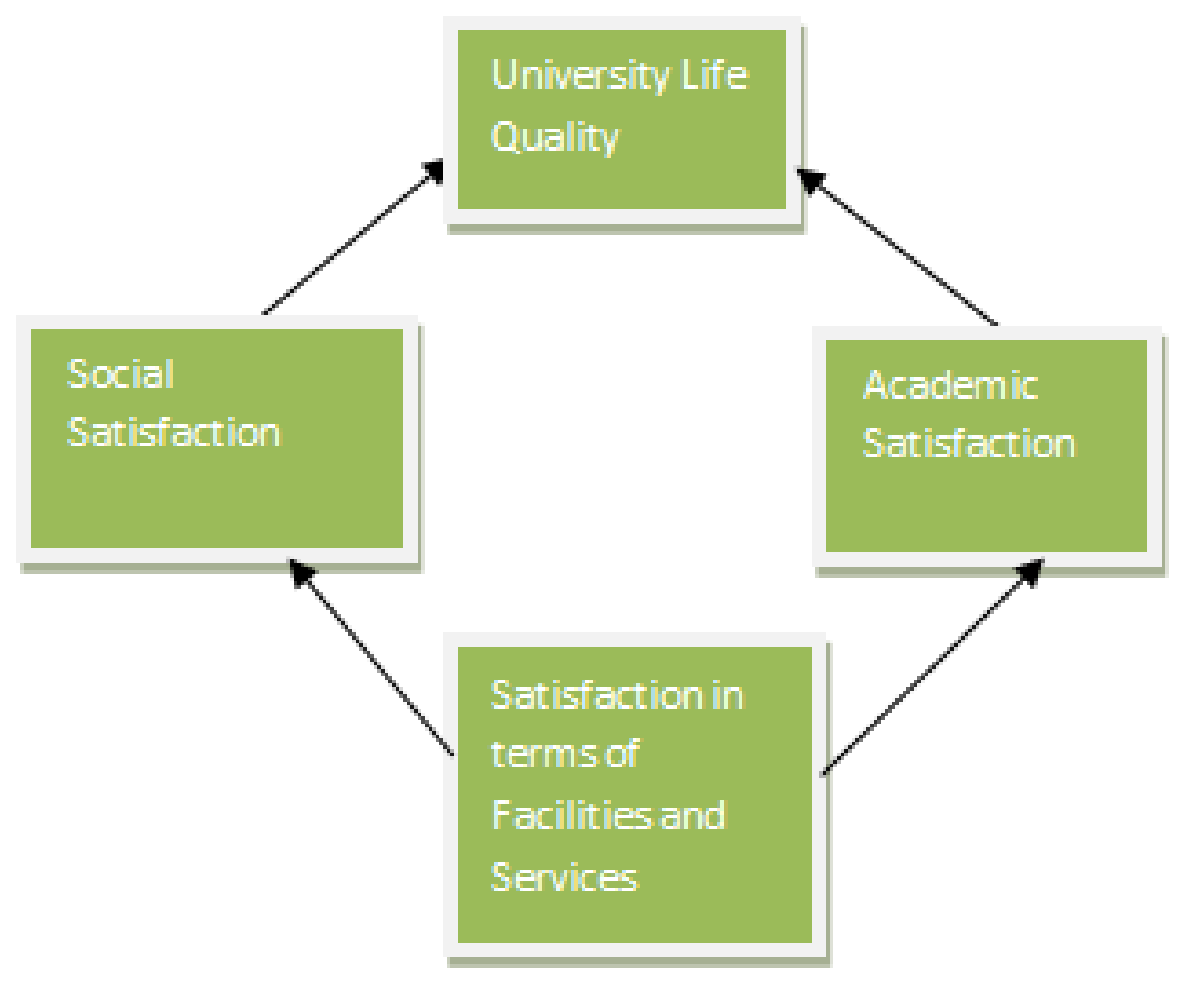

Figure 1. Sirgy, Grzeskowiak and Rahtz's (2007)

1) Social Satisfaction: It includes relationships with friends, leisure time, family relationships, health state of the individual, health state of the family, faculty, level of family income, university career, personal economic state and university friendship (Sirgy et al., 2007). Satisfaction with the accommodation facilities of the campus (quality of housing, being well-maintained and safe, location, the usefulness of the rooms, dormitory activities), satisfaction with international programs and services (the services offered by the programs and services, encouraging the students in these departments), satisfaction with the spiritual support of the programs and services (support of the university to spiritual life, arrangements in this regard, worship places), satisfaction from the clubs and parties (unity and solidarity, clubs, club experiences), satisfaction from sporting events (inter-university competitions, competitions of women and men teams, sports fields, sporting events), satisfaction with the recreation activities (sponsored activities, indoor sports, concerts in the campus) are involved in the framework of social satisfaction.

2) Academic Satisfaction: It involves satisfaction with the university; satisfaction with instruction methods (use of technology, interactive course), satisfaction with the classroom environment (the location of the class, seating order in the class, heating and sound order in the class, number of students in the class, the size of the class), workload in the class (work overload, level of work difficulty), satisfaction with the academic aspect of university (the recognition of the university, the fact that professors are famous), and satisfaction with academic diversity (multiculturalism of the faculty, ethnicity and gender diversity).

University Life Quality Conceptual Model is a model that embraces university life with its all dimensions. All the dimensions discussed in the model may affect the individual's assessment of the university both positively or negatively. The most important goal of university students in their lives is to use their special abilities and tendencies. Other expectations are to have a postgraduate education, prepare for the profession and find a job after graduation. If universities have these features, they can be preferred by students.

ULQ influences the environments which includes the university's qualifications of formal and informal life together, in which students feel happy and secure and are satisfied with their social relations. Universities, which prepare students for life both academically and socially, and which aim to give them certain knowledge and values together with skills, have a very important place in the life of students. There is a consensus among families, teachers, administrators and students that schools should be the places which increase the learning of students at the maximum level and where students are satisfied with faculty members and what they learn (Sar1, 2007).

The two important elements that should be taken into account while preparing the objectives of the formal education programs of educational institutions at all levels around the world are the needs of the individual and those of the society. If the objectives of the universities' education programs are determined by considering these 
two needs, individuals and societies will be satisfied with the education received. Therefore, it can be said that the education received involves the principle of being life-oriented and that a unity of purpose can be reached among the individual, society and program. These three concepts (individual, society and program) are the critical concepts for the effectiveness of educational institutions.

\subsection{University Life Quality and the Individual}

"What is the function of education?" The answer to this question is, in general, closely related to the philosophical context of education and culture, while in the individual context, it is closely related to the importance given to education by individuals, their efforts in the education process and their expectations of what the educational outcomes will bring to their lives. In other words, the response of individuals to this question within the context of the connection they have established with their own experiences (Çengel, 2017) influences their expectation from ULQ and education. In this regard, it is essential that the goals of the individual and the objectives of the university match with each other.

Herman, Reinke, Parkin, Traylor and Agarwal (2009) characterize schools as the main setting of students away from their homes and by emphasizing the impact of it on their identity developments; they state that their strategies for life are developed there. This requires schools to be the settings where all the needs of students as individuals can be met and possible support can be provided accordingly. As a life space, schools can achieve their goals as long as they support students.

In order to make the university an appropriate place to live in, it is important to take students' preferences, experiences and opinions as the residents of school (Tangen, 2009). The views of each student regarding the school differ. For some students, while the school is considered a fun setting, it may be a boring place for others. These features indicate individual differences. Individual differences are the realities upon which faculty members should put significant emphasis. Readiness level, past learnings, motivation, learning style, personality, and cognitive, affective and psychomotor skills of each student differ from each other.

Considering the fact that a student spends approximately 8.660 hours until the end of primary school education from the first grade to the end of the eighth grade, approximately 11.880 hours until the end of secondary school education and approximately 16.200 hours until the end of the tertiary education, it is understood how important student experience is. Students' experiences regarding the school can have an impact on their decision to drop out of school or to attend a higher institution of education (Ayık \& Ataş-Akdemir, 2015). Today, the qualifications that are looked for in individuals have changed, and thinking locally but behaving globally, being sensitive to problems, solving problems, having high communication skills etc. have become the basic individual competencies of the age (Akdoğan, 2014). Universities should be the institutions that train individuals so that they develop these qualifications. Bearing in mind the fact that school life includes positive or negative experiences and emotions, that its consequences holistically affect the social setting in which the individual lives, and considering the time spent at school, the significance of school life quality will be felt better (Argon \& İsmetoğlu, 2016).

University involves teacher-student, student-student, teacher-teacher, student-administrator, teacher-family and student-family relationships. At universities where these relationships have a significant role, it is necessary to create environments in which the activities that will enable the social development of students are organized, the students are valued and feel as an important individual. The education provided at universities is not limited to formal learning. There are multi-faceted relationships at universities (Aydın, 2010). ULQ affects many variables in the education process of individuals such as the sense of belonging, the attitudes towards the profession, etc.

The fact that schools are the places where laws, norms, codes of conduct and social acceptability are taught for forming the personality of the student increases the importance of schools more (Argon \& Kösterelioğlu, 2009). Lang, Wong and Fraser (2005) state that the relationships with teachers in particular determine ULQ. Accordingly, the student who sets good relationships in the school and who develops mutual trust, respect and love will have a high level of ULQ (Gedik, 2014).

ULQ involves both cognitive assessment of university life and affective experiences during university life. While cognitive content indicates the satisfaction from university life, emotional content expresses the frequency of positive emotions occurring during the years at university ( $\mathrm{Yu} \&$ Kim, 2008). Special attention is given to ULQ by the administrators and teachers because ULQ is related to the academic achievement of students. Students' responses to their teachers and their commitment to school are important in the school effectiveness (Epstein \& Mc Partland, 1976).

The concept of ULQ provides a perspective to conceptualize the needs of students, to define the services conducted and to assess the programs carried out (Tüzün et al., 2003). ULQ is related to the individuals' hopes and expectations, and what they think they lack in themselves. Individuals compare the social situations they perceive with others and reveal their own states and expectations. Many variables such as age, gender, education level, socio-economic level, state of health and religious beliefs play a role in shaping the hopes and expectations of individuals (Durmaz \& Atmaz, 2006). Within this context, it can be said that the concept of ULQ is influenced by various individual factors. In order for students to enjoy school, embark school and feel that they belong to school, 
the experiences at school are highly important. High ULQ enhances the participation of students to school life (Karatzias, Papadioti-Athanasiou, Power \& Swanson, 2001).

In the studies conducted on young communities, it is reported that young people aged between 18-24 have lower life quality in mental area compared to physical area, and that there are riskier behaviors for mental health, perceived health and health with age (Zahran, Zack, Mary, Smiley, Hertz, Marci \& Vernon, 2007). The fact that university students are at this age range indicates the importance of the researches that can serve to improve ULQ. In order to develop academic, social and personal aspects of students, having high ULQ is seen to be an important and effective factor (Alaca, 2011; Alpkaya, 2010).

It is important that an individual evaluates their own life and finds it positive. In this regard, life quality is a subjective satisfaction or result that the individual evaluates (Tekkanat, 2008). It is important that universities make planning by determining their objectives and priorities and address the needs and expectations of the students in a dynamic framework. It is a high probability that the students studying in public universities and those studying in private universities have different perspectives in evaluating ULQ, because private universities are paid but public universities are free or paid much less. Since they pay a cost to private universities, the students at private universities may be more likely to consider ULQ more critically. Besides, another factor affecting the life quality of private universities is the cost of the university to the individual economically. At this point, the individual questions whether the university provides them a qualified education or not. Within this context, university students can approach the school from the perspective of customer satisfaction while assessing the school. Differences can be observed in the attitude of faculty members due to this economic impact. Students also consider how much the university contributes to their individual career development while assessing ULQ (Dicker, Garcia, Kelly $\&$ Mulrooney, 2018). The fact that the students believe they will have a good job after graduating from the faculty can lead them to have positive views of the university.

\subsection{University Life Quality and the Society}

Universities play an important role in the scientific, economic, technological, social and cultural developments of societies. As a dynamic institution that provides scientific and technical knowledge and professional skills to improve social and individual life quality, university provides a transition between social strata (Scott, 2002). Individuals acquire the kinds of behaviors and professions that the society needs. The social setting within and outside the school as well as the social setting after graduation, are important for the university student. For this reason, social needs should not be ignored at universities. Sociological approaches to ULQ studies are gradually having more and more influence because assessing ULQ depends on the people experiencing it. University should support the social relationships or social integration of individuals and should create and develop individual and social responsibility for individuals (Williams \& Batten, 1981). The quality of school life is not only limited to academic learning; it is an important process affecting social cohesion or participation. During the instructional processes, mutual interactions of the students, administrator-teacher-student-parent relationships, understanding the elements of social life and building the sense of identity are important determinants (Argon \& Ismetoglu, 2016).

It is possible to gather the indicators that researchers use regarding ULQ in four groups:

1. Personal inner space (values, beliefs, desires, personal goals, coping with problems etc.)

2. Personal social space (family structure, level of income, job, facilities provided by the community etc.)

3. External nature environment space (air, water quality etc.)

4. External social environment space (cultural, social and religious institutions, social facilities like school and health services, security, transportation and shopping) (Eser, 2004).

The age we are in is the age of information society. In information societies, the institution that will actively take part in producing information, making use of it and disseminating it will undoubtedly be the school. The fact that the school has an organizational culture in accordance with information society will also support the competence of the human type it will educate to meet the needs of the information society. Schools should be able to develop entrepreneur individuals with international competitiveness who can take initiatives (Argon \& İsmetoğlu, 2016).

Mok and Flynn (2002) emphasizes that the purpose of education is not only the transfer of knowledge or the development of learning skills but also "to raise all individuals as a member of society and to acquire the basic skills necessary for citizenship in a pluralist and democratic society". In order to make students acquire these skills, it is necessary for the school environment to have a democratic climate. If the faculty is democratic, the student can develop positive feelings towards the faculty. The importance given to ULQ has been increasing in order for the students not to have negative feelings towards school (Gedik, 2014).

There is a bi-directional relationship between education and society. Education has the ability to influence all the segments of society. Likewise, education process can be affected by many formal and informal factors as it does not have an isolated structure from social life. Factors like the institutional and physical characteristics of the school, 
teachers, family, mass media and peer groups can influence the institution and lead the students to move away and become alienated from the education process (Avc1, 2012: 28). One of the factors affecting ULQ is the social activities within school. The socialization process is a significant variable in ULQ. By directing their students to social activities, faculty members will support ULQ.

As the increasing number of students in higher education and the total cost of education force the capacity of public resources, housing, sports and catering services of universities are affected negatively. All these underlying negative impacts decrease ULQ (Y1lmazer, 2016). Limited budget is allocated for the physical and social experiences and leisure time activities of students and for meeting their individual needs. This creates a situation that may negatively affect ULQ (Günay \& Günay, 2011). In order to enhance life quality at universities, there is a need to educate individuals with the characteristics society necessitates. These needs may be quantitative or qualitative needs.

\subsection{University Life Quality, Open Curriculum and Hidden Curriculum}

The perceptions approaching schools with a more holistic perspective object to academic performance as the only indicator of a "good school" and emphasize improving students' creativity skill and supporting their physical, affective and social well-beings (Weston, 1998). Universities are responsible for the social and individual development of students, in other words, the development of students as a "whole" (Kabeta, 1999). When the open (formal) education programs in the world are examined, it can be seen that holistic development of the individual is important. Schools are the institutions that are responsible for developing individuals holistically in cognitive, affective and psychomotor fields. A university with a positive ULQ should have a characteristic that supports holistic development.

ULQ affects and is affected by both the formal curriculum and the hidden curriculum. While the formal curriculum involves the defined acquisitions and objectives, the hidden curriculum involves the values transferred by social relationships or teachers (Giroux, 2001). Hidden curriculum is the unforgettable message that the individual acquires via experience (Martin, 2014). It can be concluded from this definition that hidden curriculum leaves permanent traces on students. In order to examine the quality of school life, it is important to note that the formal and informal structure of the school affects the quality of school life (Özdemir, Kılınç, Öğdem \& Er, 2013). In this regard, the physical environment of the school, the comfort of classes, the official ceremonies in the school, and various entertainment activities can be arranged within the framework of student-oriented principle. It is a predictable situation that there can be an increase in ULQ of the schools and classrooms with positive hidden curriculum. The reason for this is that there is a linear relationship between hidden curriculum and school life quality. As ULQ increases, hidden curriculum has more positive characteristics (Elitok Kesici, 2010).

When faculty members prefer the type of communication in their open and hidden messages that will bring positive behaviors, it can be expected that ULQ will increase and hidden behaviors will turn to positive. Therefore, the function of acquiring positive behaviors, which is in the definition of education, can be fulfilled. Without effective communication in the classroom, neither the objectives of the formal curriculum nor acquiring positive characteristics function of hidden curriculum can be achieved. Hidden curriculum is approached in the informal structure of the school. ULQ refers to a school climate that supports students' school security and learning (Austin, Hanson, Bono \& Cheng, 2007). These characteristics are related to affective field objectives and hidden curriculum involves the affective field gains such as attitudes, requests and etc. The variables of ULQ have some characteristics that have to be taken into consideration both in the hidden curriculum and in the formal curriculum. If it is desired to ULQ at universities, it is necessary to conduct the hidden curriculum in a healthy manner.

\section{Method}

In this research, "literature review" method is used to examine the studies of ULQ. Literature reviews are used in educational researches in order to guide the future researches and applications by revealing the important links and forms in the literature (Minner, Levuy \& Century, 2010). In this regard, data is obtained by reviewing related articles, books, theses and dissertations. According to Karasar (2011: 77), screening researches are the research approaches aiming to describe a situation that existed in the past or exists in present just as it is. In this study, secondary data resources regarding ULQ published in the past have been investigated. With this aspect, the study is in the literature screening model. According to Erkus (2009: 86), literature reviews are conducted on a specific field and it is the investigation of reviewing the cumulated studies. In this method, the advantageous and disadvantageous aspects of the studies are discussed critically and important inferences are made for new studies. In the study, data is searched in the databases like EBSCOhost, ERIC and ISI Web of Science and then, in Google Scholar search engine by typing the keyword "university life quality". Full text articles have been reached as a result of this search. Besides, various books, theses and dissertations related to the subject are used. In these resources, the definition of ULQ, its scope and relationships with other concepts are examined. 
In this research, 42 full-text journal articles are reached; 12 books and 13 theses and dissertations are examined. In this regard, 67 resources have been reached. Then, the definition of ULQ, the concept of ULQ, individual and social characteristics of ULQ and its relationship with the open and hidden curriculums are examined separately.

In the study process, a three-stage method is followed (Karaçam, 2013):

1) Determining the screening method and selection criterions: In order to examine the studies conducted and identify the characteristics and results of ULQ researches clearly during the research process, quantitative, qualitative and mixed method researches are examined. It is noted that these studies have been published in the peer-reviewed journals where these research designs are used.

2) Screening (Reviewing) process: At this stage, first of all, queries are made with keywords in the databases.

3) Analysis process: Similar and different findings of the articles are summarized.

\section{Discussion and Conclusions}

Determining the way students perceive ULQ by the students, which creates an environment formed of the elements affecting students' school achievements and motivations and where they can be happy with all aspects is essential for the effective development of the educational activities, for the improvement of students and in terms of community development.

When we answer the question of how a university with high level of ULQ can be, it is that the academic and social life of this school and the facilities and services should be of high quality. In order to achieve this result, universities should contribute to leisure activities that improve friendship, health problems of students and their career development. Besides, housing opportunities of the campus should be qualified, and students' spiritual lives, social, sports and cultural activities should be supported. Academic development of students should also be supported in a qualified university. Academic development can be carried out by directing students towards scientific congresses and participating in seminars as well as qualified classroom settings. The methods and instructional technologies that enable students to be active in the classrooms should be used and the classroom setting should be organized in accordance with teaching. The fact that the university has an environment appropriate to multiculturalism positively affects life quality.

If individual-oriented education principle is taken into account at universities, ULQ can increase the level of adopting and embracing the school by the students, respecting and loving their teachers and friends, and their social and academic achievement. In individual needs are not concerned, ULQ decreases and this can lead to a school environment that nurtures and develops such negative behaviors as vandalism, violence and intimidation. Therefore, ULQ should be considered as important for the school and educational administrators to be able to comprehend student perceptions of ULQ, identify the deficiencies in ULQ, and take measures regarding all these (Erden \& Erdem, 2013).

Three important elements of education systems are teachers, students and instructional programs. The fact that students have a qualified university life will be the determinant of their qualifications regarding their professions. For example, the competency of faculty members in terms of professional qualifications directly affects students in being trained as good citizens. Today, teachers play an important role in the development of students (Evers, Tomic \& Brouwers, 2004). In this regard, faculty members should set a good example to their students with their knowledge, attitudes and behaviors. In a study conducted, it is revealed that the positive relationship between students and teachers is related to academic achievement (Roorda, Koomen, Spilt \& Oort, 2011). In another study, it is emphasized that the most important element affecting ULQ is the faculty member (Munasinghe \& Rathnasiri, 2011). A good instructional program can produce bad results in the hands of an unqualified faculty member. At the same time, a bad program can raise very good students in the hands of a qualified faculty member. Individual qualifications of the faculty member and instructional skills can affect student behaviors more than the formal curriculum.

Determining the expectations of students regarding university life has a significant impact on raising the quality and service standards of the university. The conclusion that the realization level of the expected behaviors from students is relatively low can be reclaimed by enhancing ULQ. According to a research conducted, university students have a moderate level of ULQ (Özdemir, 2012; Özdemir et al., 2013). This situation necessitates the organization of all elements constituting the school in accordance with the requirements of the age as school settings have a great impact on the individual's long-term life quality and outcomes of life (Argon \& İsmetoğlu, 2016). If this organization can be ensured, underdeveloped societies can reach the development level of developed societies.

The views of the students about the school organization should be deemed important because the majority of students' lives is spent at school and the primary reason for the existence of schools is not the teachers and administrators but the students and society (Şişman \& Turan, 2001). The social environment in which the society lives can affect ULQ either positively or negatively. In the literature, there are researches supporting that the socio-economic-cultural level has influences on the students' ULQ. For example, Eshelman (2013) emphasizes that individuals with high socio-economic levels can adapt 
to their environment more easily and open themselves more in terms of the plans they make. In many studies conducted, it is revealed that the schools with low socio-economic level have low life quality, whereas the schools with high socio-economic level have high life quality (Elitok Kesici, 2010; Sarı, 2007; Aldinç et al., 2004).

Although different opportunities are presented for gifted students in the existing universities, many students graduate from university by being deprived of the experiences they need or they leave the university because the arrangements that will involve all the students and that will improve their university life are not presented (Casazza \& Bauer, 2006). The reason for this conclusion may be the deficiencies in school culture and democratic processes. In the studies where universities are considered as areas that can contribute more to the democratic process, school culture is investigated as school life quality (Doğanay \& Sar1, 2006). Furthermore, school culture is a feature that is influenced by open and hidden curriculum. Positive school culture creates positive hidden curriculum and positive hidden curriculum enhances ULQ.

The objectives of education programs should be determined by taking the needs into consideration. By focusing on the needs of the individual and society in particular and preparing the objectives of higher education program accordingly, the quality of the education received will be enhanced.

There has been a significant increase in the number of studies conducted regarding the concept of ULQ in the international literature since the early 1990s (Al-Zboon, Ahmad \& Theeb, 2014). Within this context, the effects of ULQ on the education process have been examined by many researchers. For example, it is revealed by several studies that ULQ affected academic achievement student behaviors and performance (Ostroff, 1992), early school dropout (Pawlovich, 1983), health problems, social relationships, self-development (Sarı \& Cenkseven, 2008), and school commitment (Kalaycı \& Özdemir, 2013).

Furthermore, ULQ has been examined both disciplinary and interdisciplinary in many areas such as instruction programs, educational sociology, opportunities, satisfaction with school life, educational psychology, the individual, environment and activity, public health (Y1lmazer, 2016), happiness and satisfaction with university life (Sirgy et al., 2007; Yu \& Kim, 2008; Quality of College Life Survey Report, 2009).

Students who attend schools in which physical, emotional and social development areas are supported are more social, more open to learning, have positive behaviors and attitudes, and adapt to life and higher education institutions more easily. Similarly, learning and communication environment that increases student satisfaction brings together less behavioral disorder, discipline problems, student absenteeism and school dropout. All these lead to the fact that schools should improve their life quality (Argon \& İsmetoğlu, 2016). The high level of life quality at universities influences the holistic development of students and contributes to the fulfillment of the cultural, social and economic functions of education.

By investigating ULQ perceptions of students, their feelings regarding the school, their relationships with their friends, faculty members and school administrators, the activities performed at school can be acknowledged. Necessary arrangements can be made for a better faculty life quality (Gedik, 2014). Critical thinking skills acquired in faculties are also effective in perceiving faculty life as qualified (Carini, Kuh, \& Klein 2006).

It can be said that in the studies carried out on ULQ, quantitative assessments have been made in general and that they have been indirectly related to quality. However, today, there is a consensus on the fact that it will be beneficial to examine the humanitarian and cultural dimensions of educational environments in order to obtain better information regarding the quality of education today (Wilson, 1980).

Universities should make their academic and social lives, facilities and services more qualified. Therefore, they can contribute to both community development and individual development. Furthermore, universities add some features to their open and hidden curriculum elements so that they will enhance ULQ. It is determined that in order to improve ULQ, comparative studies on the different applications among countries and qualitative researches, which investigate the subject deeply, are required. Besides, there is a need for qualitative and quantitative researches in the literature which aim to reveal the similarities and differences of the factors affecting ULQ of public and private universities.

\section{REFERENCES}

[1] Akyüz, G. (2006). Geriatrik hastalarda yaşam kalitesi. Türkiye Fiziksel Tip ve Rehabilitasyon Dergisi, 52, 57-59.

[2] Aldinç, H., Aytar, B., Demetçi, M. E., Seçen, E. A., Şahin, A., \& Y1lmaz, H. (2004). Ankara ilinden seçilen birinci basamak sağlık kuruluşlarına başvuran 18 yaş ve üzeri kişilerin medikososyal özelliklerine göre yaşam kalitelerinin karşılaştırılması. Gazi Üniversitesi Tip Fakültesi Halk Să̆lı̆gl AD. (Retrieved from http://www.sabem.saglik.gov.tr/Akademik_Metinler/goto.a spx?id=2614 on 15.04.2007).

[3] Akdoğan, A. (2014). Uluslararası eğitim programlarında insan yetiștirme modeli (Retrieved from http://ookgm.meb.gov.tr/meb_iys_dosyalar/2016_02/2609 5652_ieitimkongresikitab.pdf on 15.03.2019).

[4] Alaca, F. (2011). İki dilli olan ve olmayan öğrencilerde okul yaşam kalitesi algısı ve okula aidiyet duygusu ilişkisi. Unpublished master thesis, Çukurova Üniversitesi Sosyal Bilimler Enstitüsü, Adana. 
[5] Alpkaya, G. (2010). Okul müdürlerinin sahip olduğu feminen-maskulen özelliklerin okul yaşam kalitesine etkisi. Unpublished master thesis, Uşak Üniversitesi Sosyal Bilimler Enstitüsü, Uşak.

[6] Al-Zboon, E., Ahmad, J. F., \& Theeb, R. S. (2014). Quality of Life of Students with Disabilites Attending Jordanian Universities. International Journal of Special Education, 29(3), 93-100.

[7] Argon, T., \& İsmetoğlu, M. (2016). Öğrencilerin lise yaşam kalitesi algıları ile okula bağlılık düzeyleri arasındaki ilişki. Eğitim ve Öğretim Araştırmaları Dergisi, 5(1), 238-249. DOI: $10.17719 /$ jisr.2017.1799

[8] Argon, T., \& Kösterelioğlu, M. A. (2009). Üniversite öğrencilerinin üniversite yaşam kalitesi ve fakülte kültürüne ilişkin algıları. Elektronik Sosyal Bilimler Dergisi, 8(30), 43-61.

[9] Austin, G., Hanson, T., Bono, G., \& Cheng, Z. (2007). The achievement gap, school well-being, and learning supports. CHKS Factsheet, 8. (Retrieved from

http://www.closingtheachievementgap.org/cs/ctag/view/res ource on 24.12.2012).

[10] Avc1, M. (2012). Eğitimde Temel Bir Sorun: Yabanc1lasma/A Basic Problem in Education: Alienation. Atatürk Üniversitesi Sosyal Bilimler Enstitüsü Dergisi, 16(3), 23-40.

[11] Aydın, M. (2010). Eğitim yönetimi (9 $9^{\text {th }}$ Edition). Ankara: Hatipoğlu Yayınevi.

[12] Ayık, A., \& Ataş-Akdemir, Ö. (2015). Öğretmen adaylarının okul yaşam kalitesi ve okula yabancılaşma algıları arasındaki ilişki. Kuram ve Uygulamada Ĕ̈itim Yönetimi Dergisi, 21(4), 429-452.

[13] Carini, R. M., Kuh, G. D., \& Klein, S. P. (2006). Student engagement and student learning: Testing the linkages. Research in higher education, 47(1), 1-32.

[14] Casazza, M. E., \& Bauer, L. (2006). Access, opportunity, and success: Keeping the promise of higher education. Greenwood Publishing Group.

[15] Çengel, M. (2017). Eğitim İsteği: Açık ve Örtük Program Bağlamında Bir İnceleme. İlkögrretim Online, 16(2), 601-613.

[16] Doğanay, A., \& Sarı, M. (2006). Öğrencilerin üniversitedeki yaşam kalitesine ilişkin algılarının demokratik yaşam kültürü çerçevesinde değerlendirilmesi (Çukurova Üniversitesi örneği). Türk Eğitim Bilimleri Dergisi, 4(2), 107-128.

[17] Durmaz, B., \& Atamaz, F. (2006) İnme ve hayat kalitesi. Türkiye Fiziksel Tip ve Rehabilitasyon Dergisi. 52 (special annex), 45-49.

[18] Dicker, R., Garcia, M., Kelly, A., \& Mulrooney, H. (2018). What does 'quality'in higher education mean? Perceptions of staff, students and employers. Studies in Higher Education, 1-13. DOI: 10.1080/03075079.2018.1445987.

[19] Elitok-Kesici, A. (2010). Ortaöğretim öğretmenlerinin sınıf içi iletişimde kullandıkları örtük programın özellikleri. Unpublished doctoral dissertation, Adnan Menderes Üniversitesi Sosyal Bilimler Enstitüsü, Aydin.
[20] Epstein, J. L., \& McPartland, J. M. (1976). The concept and measurement of the quality of school life. American Educational Research Journal, 13(1), 15-30.

[21] Erden, A., \& Erdem, M. (2013). İlköğretim okullarında okul yaşamı kalitesi: Van ili örneği. Hacettepe Üniversitesi Ĕgitim Fakültesi Dergisi, 28(28-3), 1-15.

[22] Erkuş, A. (2011). Davranış bilimleri için bilimsel araştırma süreci. Ankara: Seçkin Yayıncılık.

[23] Eser, E. (2004). Yaşam kalitesinin sınıflandırılması ve sağlıkla ilgili yaşam kalitesinin ölçümü. 1. Sağllkta Yaşam Kalitesi Sempozyumu Program ve Özet Kitabl, 4-6. Retrieved from

http://www.bayar.edu.tr/ saykad/g erhan1.html on 15.03.08)

[24] Eser, E., Yüksel, H., Baydur, H., Erhart, M., Saatli, G., Özyurt, B. C., ... \& Ravens-Sieberer, U. (2008). Çocuklar İçin Genel Amaçlı Sağlıkla İlgili Yaşam Kalitesi Ölçeği (Kid-KINDL) Türkçe Sürümünün Psikometrik Özellikleri. Türk Psikiyatri Dergisi, 19(4): 409-417.

[25] Eshelman, A. (2013). Socioeconomic status and social class as predictors of career adaptability and educational aspirations in high school students. Unpublished doctoral dissertation, Southern Illinois University Carbondale (UMI: 1548912).

[26] Evers, W. J., Tomic, W., \& Brouwers, A. (2004). Burnout among teachers: Students' and teachers' perceptions compared. School Psychology International, 25(2), 131-148.

[27] Gedik, A.(2014). Ortaöğretim öğrencilerinde okul yaşam kalitesi bağlamında okula yabancılaşma. Unpublished master thesis, İn̈nü Üniversitesi Ĕ̌itim Bilimleri Enstitüsü, Malatya.

[28] Giroux, H. A. (2001). Theory and resistance in education: Towards a pedagogy for the opposition. Greenwood Publishing Group.

[29] Günay, D., \& Günay, A. (2011) Quantitative developments in turkish higher education since 1933. Journal of Higher Education and Science, 1(1), 001-022.

[30] Herman, K. C., Reinke, W. M., Parkin, J., Traylor, K. B., \& Agarwal, G. (2009). Childhood depression: Rethinking the role of the school. Psychology in the Schools, 46(5), 433-446.

[31] Kabeta, M. H. (1999). University productive sector linkages for quality of life improvement. Institute Of Distance Education, 112.

[32] Kangal, A. (2012). Üniversite yaşam kalitesi ölçeği'nin Türkçe uyarlaması: Geçerlik ve güvenirlik çalışması. e-Uluslararası Ĕ̌itim Araştırmaları Dergisi, 3(1), 16-32.

[33] Kalayc1, H., \& Özdemir, M. (2013). Lise öğrencilerinin okul yaşamının niteliğine ilişkin algılarının okul bağlılıkları üzerine etkisi. Gazi University Journal of Gazi Educational Faculty (GUJGEF), 33(2), 293-315.

[34] Karaçam, Z. (2013). Sistematik derleme metodolojisi: Sistematik derleme hazırlamak için bir rehber. Dokuz Eylül Üniversitesi Hemşirelik Yüksekokulu Elektronik Dergisi, 6(1), 26-33. 
[35] Karasar, N. (2011). Bilimsel araştırma yöntemleri. Ankara: Nobel Yayıncilık.

[36] Karatzias, A., Papadioti-Athanasiou, V., Power, K. G., \& Swanson, V. (2001). Quality of school life. A cross-cultural study of Greek and Scottish secondary school pupils. European Journal of Education, 36(1), 91-105.

[37] Lang, Q. C., Wong, A. F., \& Fraser, B. J. (2005). Teacher-student interaction and gifted students' attitudes toward chemistry in laboratory classrooms in Singapore. Journal of Classroom Interaction, 18-28.

[38] Martin, L. (2014). The hidden curriculum exposed: How one outreach program bridges cultural capital and cultural wealth for Latina/o community college transfer students. Unpublished doctoral dissertation, UCLA. (Retrieved from http://www.escholarship.org/uc/item/606359hk on 17.03.2 019

[39] Minner, D. D., Levy, A. J., \& Century, J. (2010). Inquiry based science instruction-what is it and does it matter? Results from a research synthesis years 1984 to 2002. Journal of Research in Science Teaching: The Official Journal of the National Association for Research in Science Teaching, 47(4), 474-496. DOI: 10.1002/tea.20347.

[40] Munasinghe, M. A. T. K., \& Rathnasiri, U. A. H. A. (2011, January). Undergraduates perception on quality in higher education. In International Conference on Qualitative and Quantitative Economics Research (QQE). Proceedings (p. 1B). Global Science and Technology Forum.

[41] Mok, M. M. C. (2002). Determinants of students' quality of school life: A path model. Learning environments research, 5(3), 275-300.

[42] Ostroff, C. (1992). The relationship between satisfaction, attitudes, and performance: An organizational level analysis. Journal of applied psychology, 77(6), 963.

[43] Özdemir, S., Kılınç, A. Ç., Öğdem, Z., \& Er, E. (2013). Eğitim Fakültesi Öğrencilerinin Fakülte Yaşamının Niteliğine İlişkin Memnuniyet Düzeylerinin Çeşitli Değişkenler Açısından İncelenmesi. Journal of Higher Education \& Science/Yüksekögretim ve Bilim Dergisi, 3(3), 228-235.

[44] Özdemir, M. (2012). Üniversite öğrencilerinin okul yaşamının niteliğine ilişkin algılarının cinsiyet ve fakülte değişkenlerine göre incelenmesi. Kuram ve Uygulamada Egitim Yönetimi Dergisi, 18(2), 225-242.

[45] Pawlovich, W. E. (1983). Quality of school life and early school leaving. Unpublished doctoral dissertation, The University of Alberta, Canada.

[46] Pekel, A. (2016). Spor yöneticiliği bölümünde öğrenim gören öğrencilerin akademik öz yeterlikleri ve üniversite yaşam kalitesi arasındaki ilişkinin incelenmesi. Unpublished master thesis, Erciyes Üniversitesi Sağllk Bilimler Enstitüsü, Kayseri.

[47] Quality of College Life Survey Report (2009). American University of Beirut Office of Institutional Research and Assessment.

[48] Roorda, D. L., Koomen, H. M., Spilt, J. L., \& Oort, F. J. (2011). The influence of affective teacher-student relationships on students' school engagement and achievement: A meta-analytic approach. Review of educational research, 81(4), 493-529.

[49] Sarı, M. (2007). Demokratik değerlerin kazanımı sürecinde örtük program: düşük ve yüksek okul yaşam kalitesine sahip iki ilköğretim okulunda nitel bir çalışma. Unpublished doctoral dissertation, Çukurova Üniversitesi Sosyal Bilimler Enstitüsü, Adana.

[50] Sarı, M., \& Cenkseven, F. (2008). İlköğretim öğrencilerinde okul yaşam kalitesi ve benlik kavramı. Uluslararası Insan Bilimleri Dergisi, 5(2), 1-16.

[51] Sarı M., \& Arıkan G. (2016). Lise öğrencilerinde okul yaşam kalitesinin incelenmesi. Uluslararası Güncel Eğitim Araştırmaları Dergisi (UGEAD), 2(1), 66-77.

[52] Schwartz, S. H., \& Bilsky, W. (1987). Toward a universal psychological structure of human values. Journal of personality and social psychology, 53(3), 550-562.

[53] Sirgy, M. J., Grzeskowiak, S., \& Rahtz, D. (2007). Quality of college life (QCL) of students: Developing and validating a measure of well-being. Social Indicators Research, 80(2), 343-360.

[54] Sirgy, M. J., Lee, D. J., Grzeskowiak, S., Grace, B. Y., Webb, D., El-Hasan, K., ... \& Kangal, A. (2010). Quality of college life (QCL) of students: Further validation of a measure of well-being. Social Indicators Research, 99(3), 375-390.

[55] Şişman, M., \& Turan, S. (2001). Eğitimde toplam kalite yönetimi. Ankara: Pegem A Yayıncılı.

[56] Tangen, R. (2009). Conceptualising quality of school life from pupils' perspectives: A four - dimensional model. International Journal of Inclusive Education, 13(8), 829-844.

[57] Tekkanat, Ç. (2008). Öğretmenlik bölümünde okuyan öğrencilerde yaşam kalitesi ve fiziksel aktivite düzeyleri. Unpublished master thesis, Pamukkale Üniversitesi Sağllk Bilimleri Enstitüsü, Denizli.

[58] Tüzün, E. H., \& Eker, L. (2003). Sağlık değerlendirme ölçütleri ve yaşam kalitesi. Sağlık ve Toplum, 13(2), 3-8.

[59] Weston, R. (1998). Quality of school life in government, catholic and other private secondary schools: Views of students and their parents. Australian Institute of Family Studies Family Matters, 50, 56-61.

[60] Williams, T., \& Batten, M. (1981). The quality of school life (The Australian Council for Educational Research, Hawthorn, Victoria)

[61] Wilson, A. (1980). Landmarks in the literature: How powerful is schooling?. New York University Education Quarterly, 11(3), 28-31.

[62] Yılmazer, Ç. (2016). Engelli üniversite öğrencilerinin yaşam kalitesinin incelenmesi. Unpublished master thesis, Hacettepe Üniversitesi Sağlık Bilimleri Enstitüsü, Ankara.

[63] Yu, G. B., \& Kim, J. H. (2008) Testing the mediating effect of the quality of college life in the student satisfaction and student loyalty relationship. Applied Research in Quality of Life, 3(1), 1-21.

[64] Zahran, H. S., Zack, M. M., Vernon-Smiley, M. E., \& Hertz, M. F. (2007). Health-related quality of life and behaviors 
risky to health among adults aged 18-24 years in secondary or higher education-United States, 2003-2005. Journal of adolescent health, 41(4), 389-397. 